\title{
НАУКОВА ІНТЕРПРЕТАЦІЯ ТВОРЧОЇ ОСОБИСТОСТІ ПИСЬМЕННИКА: ІНТЕРДИСЦИПЛІНАРНА СТРАТЕГІЯ
}

\author{
Ольга Пуніна
}

\author{
Кандидат філологічних наук, доцент, \\ Кафедра теорії та історії української і світової літератури, \\ Донецький національний університет імені Василя Стуса (УКРАЇНА), \\ 21021, м. Вінниця, вул. 600-річчя, 21, \\ e-mail:punina@ukr.net
}

\section{РЕФЕРАТ}

Mema. Метою наукового дослідження $є$ пошук інтердисциплінарної стратегії у процесі наукової інтерпретації творчої особистості письменника як органічної єдності ії психологічної і творчої сутності. Дослідницька методика. У роботі використано теоретичні загальнонаукові методи (емпіричний, емпірико-теоретичний), що враховують узагальнення, формалізацію й абстрагування матеріалу. Це необхідно для вироблення механізму кількаступеневого аналізу - від суб'єкта творчості до його унаочнення в літературному творі й від такого психологічно-творчого унаочнення до мистецьких інтерпретацій, оперуючи такими базовими взаємозалежними категоріями, як «психотип», «креатор», «образ». Результати. У статті вироблений інтердисциплінарний підхід, за яким письменницька постать вивчається у кілька ступенів: від визначення ії психологічного типу як основи для формування стратегії літературно-художньої творчості до виявлення стильової домінанти креатора, що презентує взаємозв'язок твору і самоактуалізованого творця, і від усвідомлення психологічно-творчої природи письменника до аналізу художньоінтерпретаційних моделей креатора (художнього образу творчої особистості), запропонованих образотворчим мистецтвом, кінематографом і театром. Наукова новизна. У статті вперше артикульовано інтердисциплінарну стратегію наближення до творчої особистості письменника як умовний рух дослідження «психотип $\rightarrow$ креатор $\rightarrow$ образ». Практичне значення. Матеріал статті необхідний для подальшого вивчення життєтворчості письменника, актуалізації його творчої особистості як ключової ланки істориколітературного процесу. особистість.

Ключові слова: інтердисциплінарність, психотип, креатор, образ, письменник, творча

\section{SCIENTIFIC INTERPRETATION OF THE CREATIVE PERSONALITY OF THE WRITER: AN INTERDISCIPLINARY STRATEGY}

\author{
Olha Punina \\ Ph.D. in Philology, Assistant Professor, \\ Department of Theory and History of Ukrainian and World Literature, \\ Vasyl' Stus Donetsk National University (UKRAINE), \\ 21021, Vinnytsia, 21, 600-richchia str., \\ e-mail: punina@ukr.net
}

\begin{abstract}
Aim. The purpose of scientific research is the search for an interdisciplinary strategy in the process of scientific interpretation of the creative personality of the writer as the organic unity of its psychological and creative essence. Methods. The theoretical general scientific methods (empirical, empirical-theoretical) are used in the work, taking into account the generalization, formalization and abstraction of the material. This is necessary in order to develop a mechanism for multi-level analysis - from the subject of creativity to his presentation in the literary work and from such a psychological and creative presentation to artistic interpretations, operating on such basic interdependent categories as «psychotype», «creator», «image». Results. An interdisciplinary approach is developed in which the writer's figure is studied in several stages: from the definition of its psychological type as
\end{abstract}


the basis for the formation of a strategy of literary and artistic creativity to the discovery of the style dominant of the creator, presenting the relationship between the work and the self-actualized creator, and from the perception of the psychologically - the creative nature of the writer to the analysis of the artistic and interpretive models of the creator (the artistic image of the creative personality) proposed by the art, cinematography and theater. Scientific novelty. The article is for the first time articulated an interdisciplinary strategy of approaching the writer's creative personality as a conditional movement of the study «psychotype $\rightarrow$ creator $\rightarrow$ image». Practical meaning. The material of the article is necessary for further study of the writer's life-creativity, updating his creative personality as a key part of the historical-literary process.

Key words: interdisciplinarity, psychotype, creator, image, writer, creative personality.

Наукова інтерпретація творчої особистості письменника - як органічної єдності їі психологічної і творчої сутності - слушно вимагає вироблення такої інтердисциплінарної стратегії дослідження, що дозволить виявити взаємозалежність між суб'єктом літературно-художньої творчості та результатом його креативної діяльності, водночас зумовленість психологічно-творчою природою автора такого мистецького продукту, де його обрано за об'єкт зображення i осмислення (скульптура, живопис, кіно, театр тощо). У пошуку цієї інтердисциплінарної стратегії дослідження нагальною є потреба застосувати механізм кількаступеневого аналізу - від суб'єкта творчості до його унаочнення в літературному творі й від такого психологічно-творчого унаочнення до мистецьких інтерпретацій, оперуючи такими базовими взаємозалежними категоріями, як «психотип», «креатор», «образ».

За доречними спостереженнями Івана Франка у класичній праці з психології художньої творчості, «Із секретів поетичної творчості» (1898), пізнання поетичної вдачі як окремого психічного типу, позначеного основною прикметою - еруптивністю нижньої свідомості поета (творця), тобто «іiі здібності час від часу піднімати цілі комплекси давно погребаних вражень і споминів, покомбінованих, не раз також несвідомо, одні 3 одними на денне світло верхньої свідомості» [5, с. 64], вагоме не лише для психолога, а й літературного критика. Його увага до несвідомого у творчому процесі письменника зорієнтована на оцінці «правдивого поетичного таланту», що існує як гармонія «еруптивної сили вітхнення 3 холодною силою розумового обміркування» [5, с. 65] (випадки Гомера, Софокла, Аліг'єрі Данте, Вільяма Шекспіра, Йоганна Вольфганга фон Гете). Отже, концентрація на проблемі письменника як окремого психотипу дозволяє з'ясувати особливості психічного процесу, що, в свою чергу, зумовлюють художні константи його творчості. Так, на думку філософа Олега Кривцуна, феномен художника як особливого психологічного типу передбачає вивчення прихованих міцних форм сполученості творчого дару митця і його образу життя [9, с. 35]. Ключовим для осягнення такого феномену вчений бачить завдання виявити психологічні стани, виникнення яких провокує появу творчого акту, як ці сталі стани призводять до «згущення» певних психічних ознак і роблять їх характерними у внутрішній конституції творця [9, с. 36].

У сучасній літературознавчій парадигмі звернення до категорії психологічного типу як стійкого поєднання особистісних рис [14, с. 434] зумовлене потребою бачити витоки стильової домінанти і формування стратегії художньої творчості, основу авторського світосприйняття, компонентів змістоформи тощо. Зокрема у студіях Марії Моклиці художня література трактується як майже 
нечепаний матеріал для отримування інформації про функціонування психіки окремого суб’єкта [10, с. 68], саме тому вона береться за структуризацію модернізму як культурної епохи через психіку людини за допомогою категорії психологічного типу. На думку дослідниці, психотип письменника, утворюючись в результаті процесу самоусвідомлення, об’єктивується в його стилі [10, c. 81]. Чотири психологічні типи, запропоновані в аналітичній психології Карла Гюстава Юнга, літературознавець розглядає як чотири типи взаємин людини зі світом, варіанти пріоритетного джерела істини у внутрішньому світі людини. «Психологічний тип, - пише Марія Моклиця, - який утворюється завдяки природній домінанті у внутрішньому світі розуму або емоцій, сенсорики або інтуїціï, увиразнюється в процесі рефлексії і на якомусь етапі починає визначати стосунки людини зі світом» [10, с. 237]. Такі чотири моделі світоустрою, вербалізовані саме мистецтвом в епоху модернізму, переконує літературознавець, лягли в основу мистецьких напрямків: психологія людини інтуїтивного типу артикулюється в символізмі, внутрішній світ емоційного типу - в експресіонізмі, сенсорного типу - у футуризмі й розумового типу - в сюрреалізмі.

Знавець творчості австрійського письменника Франца Грільпарцера Сергій Бєловодський у контексті розгляду знакових фігур національної літератури акцентує на першочерговій необхідності виявлення специфіки їх особистіснотворчих феноменів [1, с. 4]. На прикладі життєтворчості поета і драматурга Франца Грільпарцера вчений зауважує, що ігнорування літературознавцями психологічних засновків художньої творчості письменника, заперечення ролі біографічного фактору по суті нівелюють своєрідність особистості митця, адже саме індивідуально-творчі фактори багато в чому визначають формування стратегії художньої творчості, творчої постаті в цілому. Творчий феномен австрійського письменника XIX століття Сергій Бєловодський бачить як складну i нелінійну систему, ядром якої є їі психотип, що інтегрує ядро особистості художника. Розуміючи під психологічним типом такий тип особистості, всі модуси соціокультурної адаптації якої детерміновані його психосоматичною організацією, дослідник аналізує як інтенсивне засвоєння Францом Грільпарцером культурного спадку минулого (поле для саморефлексіi), так і його драматичні твори в аспекті виявлення конституюючих рис та процесів розвитку художньої системи письменника [див.: 1].

У ширшому розумінні - зі складовими структури родини, спадковості, конституції митця з іï домінантами, керівної особистісної ідеї - оперує категорією психотипу літературознавець Олег Сгоров щодо російського письменника Михайла Лермонтова. Його душевною організацією, психічними схильностями, умовами формування особистості науковець пояснює лінію поведінки поетового життя і трагічний кінець, специфіку художньої творчості як психічного переживання (приміром, на героїв проектуються риси циклотимічного темпераменту 3 шизотимічними елементами самого Лермонтова - роман «Герой нашого часу», а поетичні твори відображають поетів коливний психічний ритм, зокрема йдеться про мотиви смерті, могили, сну, щезання плоті й душі). Літературознавець схильний вважати, що виявлення психологічного типу Михайла Лермонтова допоможе зрозуміти природу і механізм зображених конфліктів, 
усвідомити характер його ліричних і ліро-епічних творів, особливості поетичного мислення [4, с. 169-177]. Так серед різноманіття психологічних характеристик письменника Олег Сгоров фокусується на домінантній рисі, що визначає вектор і динаміку душевного життя та поведінки Михайла Лермонтова установка на зовнішні об’єкти (екстравертний інтуїтивний тип, якому притаманне споглядання і активний творчий уплив на об'єкт).

Літературознавець Ірина Плеханова звертається до категорії психотипу в процесі аналізу поетичних текстів 3 метою з'ясування системної взаємозумовленості світосприйняття поета, особливостей його мислення й образу висловлення про світ [17, с. 149]. В основу визначення специфіки художнього мислення вона закладає юнгіанську типологічну модель, характеризуючи принципи творчості як екстравертні чи інтровертні - екстравертний розумовий тип Микола Гумільов, інтровертний розумовий тип Вєлємір Хлєбніков, екстравертний емоційний тип Володимир Маяковський, інтровертний емоційний тип Ксенія Некрасова, екстравертний сенсорний тип Сергій Єсенін, інтровертний сенсорний тип Марина Цвєтаєва, екстравертний інтуїтивний тип Борис Пастернак, інтровертний інтуїтивний тип Осип Мандельштам. На думку дослідниці, саме опис особистості літератора, заснований на методиці Карла Густава Юнга, дозволяє обгрунтувати близькість ліричного та біографічного «я», давати характеристику світосприйняття, бачити художні прояви психологічних установок, визначати творчі можливості письменника й архетип-модус його творчого мислення (реалістичний / авангардний) [18, с. 19].

Фактично, активна методологічна експлуатація теорії психотипу швейцарського психолога Карла Густава Юнга, запропонована в праці 1921 року «Психологічні типи», сучасним літературознавством та отримані ним результати доводять доцільність наукової стратегії пошуку взаємозалежності між психологічним єством особистості письменника та ії творчою сутністю, тому цілком доцільним бачиться подальше застосування юнгіанської типологічної моделі у проекції на психографію письменника, оперування категорією психологічного типу в його розумінні. Психотип для Карла Густава Юнга - характерний зразок єдиної загальної установки, що зустрічається у багатьох індивідуальних формах, тобто готовності до конкретної реакції як суб'єктивної констеляції, поєднання психічних факторів чи змістів, яке «чи визначить образ дії у тому або іншому певному напрямку, чи сприйме зовнішній подразник у той або інший певний спосіб» [25, с. 502]. Виплекана, на думку психоаналітика Дарела Шарпа, «із широкого історичного огляду (огляду, вивчення, перегляду, перевірки) типологічних питань у літературі, міфології, естетиці, філософії і психопатології» [20], концепція психотипу Карла Густава Юнга уявляється універсальною, адже враховує саме взаємодію людини зі світом, організацію нею власного досвіду - рух психічної енергії у певному напрямку (ззовні / всередину), за допомогою якого людина орієнтується в світі.

За спостереженнями Джозефа Кемпбелла, психотипічна теорія Юнга полягає в тому, що у людській психіці наявна глибинна фундаментальна енергія, яка виявляє себе як у сексі, так і у волі до влади [8, с. 142], прагненням до цього виступають особистісні установки людини: перша - екстраверт, друга - інтро- 
верт. Особистісні установки чи то психологічні способи адаптації свідчать про готовність людської психіки діяти чи реагувати у певному напрямку, лишаючи при цьому на характері індивіда певний відбиток $[25$, с. 499,501$]$. Так, в інтроверсії рух енергії здійснюється у напрямку до внутрішнього світу людини (внутрішня реальність важливіша, важить штучно сотворений суб'єктивний світ), в екстраверсії - спрямований на зовнішній світ, об'єкт (зовнішня реальність важливіша, поведінка коригується вимогами суспільства). Формою виявлення цієї глибинної енергії (лібідо) є психологічні функції такого типу: розумовий та емоційний (раціональний клас), сенсорний й інтуїтивний (ірраціональний клас). У людському арсеналі психологічних функцій на основі спадковості й упливу довколишнього середовища домінує переважно одна із них. Для розумового типу характерно розгляд будь-яких ситуацій у відстороненій, раціональній манері, для емоційного - оцінюючи, сенсорний тип сприймає світ за допомогою органів чуття, інтуїтивний - несвідомого [20].

Реагування, діяння і сприймання особистості у певному напрямку, закладені в іiі психологічному типі, у випадку з творчою натурою підкріплюються універсальною характеристикою особистості - комплексом інтелектуальних й особистісних особливостей, що сприяють самостійній постановці проблем, генеруванню значної кількості оригінальних ідей і нешаблонному їх вирішенню, такою формою передачі досвіду, як креативність (творча потенція, творчі здібності) [11, с. 37; 13, с. 289]. Креативна складова творчої особистості письменника постає залежною від його психологічної структури. За влучною думкою психолога Павла Якобсона, художником людину робить складний процес розвитку ії природних задатків, що супроводжується перетворенням психічної будови особистості [24, с. 13]. Так, у міждисциплінарних дослідженнях із психології творчості ще кінця XIX - початку XX століття вітчизняного історика культури Дмитра Овсянико-Куликовського, спрямованих на особистість поета i лабораторію його творчості, відчитується думка про взаємовплив особливостей авторської психіки та творчості геніального письменника: невропата, меланхоліка, іпохондрика, мізантропа Миколи Гоголя із егоцентричною структурою психіки і його творчості як геніальності, що «зобов'язує і діє, та, діючи, втомлює» $[15$, с. 220$]$, або Олександра Пушкіна з неегоцентричною структурою психіки та його творчістю як розширенням особистісного «я» на весь світ [15, c. 378].

У нарисі «Геній Гете» (1899) Дмитро Овсянико-Куликовський зауважує, що для розуміння поетичного генія риси його натури відіграють першорядну роль. Тому у випадку з генієм Йоганна Вольфганга фон Гете дослідник звертається до біографічних праць, зупиняючись на психічній організації поета: відзначає його вразливість, нестійкість душевної рівноваги (протиріччя, надлишок пристрасності), витрату душевних сил на боротьбу з собою і наголошує, що саме художні твори були продуктом цісї боротьби [16, с. 180]. Перша половина життя поета, коментує Овсянико-Куликовський, позначена внутрішнім розладом через «гіперболічність» почувань: він за психічною організацією надзвичайно чуттєвий до душевних страждань і радощів, крім того, швидкі перепади від одного до іншого ще більше порушують нестійку рівновагу його душі 
[16, с. 181-182]. Йоганн Вольфганг фон Гете, продовжує психолог творчості, мав страх усвідомлення своєї неврівноваженості - в такі хвилини відчував гнітюче відчуття «психічного запаморочення», відтак навіть розумова сторона його душевного життя в юності була джерелом фаустівських мук (напружене, пристрасне, невпорядковане мислення). Для самого Гете, переконує Дмитро Овсянико-Куликовський, характерне те, про що мовив його персонаж Фауст, невдоволення жадобою істинного знання, розчарування. Це своєрідна душевна драма митця, яка супроводжувалась до того ж станом відчаю: «Паралелізм зовнішнього щастя і внутрішніх страждань, постійна зміна настроїв, переходи від захватів до смутку і навпаки, всі ці душевні приливи і відливи демонструють нам дивовижне видовище своєрідного життя духу» [16, с. 182-183].

Більшість душевних мук Гете, на думку дослідника, мали суто суб'єктивне походження - були наслідком його незвично-складної душевної організації 3 iii протиріччями і неврівноваженістю, 3 ключовим почуттям його гами коханням. Далі Дмитро Овсянико-Куликовський констатує процес душевної еволюції, зміни в поетовому духові в віці сорока років, що проявляється раціональністю, спокоєм у творчості через звернення до образотворчих мистецтв (малювання, гравюра, архітектура), захоплення рівновагою духу Спінози, наукою і філософією [16, с. 198-199]. Таким чином, за Овсянико-Куликовським, існує реальна можливість у творчої особистості виправити функціональний бік психіки. У випадку з Йоганном Вольфгангом фон Гете таке корегування відбивається на художніх творах другої половини $80-$-х років - 90-х роках: гармонійність задуму і форми пророкують епоху «еллінізму» Гете, з'яву поета-художника. Історик культури зауважує, що у цей час художня творчість Гете відзначається такою особливістю: на психічному рівні вона тісно пов'язана $з$ описаними душевними станами, які служили «не лише матеріалом для поетичної обробки, а й пружиною, що приводила в дію його поетичні сили» [16, с. 184], - у митця поетизує фантазія, з'являються образи і мотиви, в яких поет втілює свої страждання (роман «Страждання юного Вертера», драма «Фауст»). Такий процес, підсумовує Дмитро Овсянико-Куликовський, виконує функцію полегшення, тимчасового вмиротворення як необхідної умови творчості.

Проектування міркувань Овсянико-Куликовського про вплив душевної організації геніальної особистості поета на його літературну творчість у сучасну літературознавчу площину веде до осмислення категорії креатора, в основу якої доцільно закласти класичну ідею Івана Франка про тісний взаємозв'язок між твором і творцем [21, с. 130-134], унаочнену методологічною пропозицією «самототожності письменника» Григорія Сивоконя, Михайлини Коцюбинської, за якою література прочитується як «текстобіографія» твору і творчості не відчужених від особи творця [22]. Не менш знаковим маркером креатора, цієї єдності твору / творця, творчості / особи творця, є екзистенціал мистецької щирості, виведений Людмилою Тарнашинською при осмисленні літературно-критичного набутку Івана Франка і Василя Стуса. Звертаючись до літературної критики Василя Стуса, літературознавець зауважує, що він інтерпретує концепт мистецької щирості Івана Франка у такий 
спосіб: Стусові неодмінно важливо хто є носієм істинної щирості. Саме через екзистенціал мистецької щирості, зазначає Людмила Тарнашинська, критик досліджує складний симбіоз особистості як homo sapiens й особистості homo creator, «обдарованою іскрою Божою», «віддзеркалену в художньому творі поєднаність цих двох аспектів» [23, с. 80]. Дослідниця переконує, що для Василя Стуса процес поетичного становлення полягає в становленні внутрішнього Я, що «виявляє готовність до якомога ширшого саморозкриття, самовивільнення в слові, а відтак „самоіснування” в художньому просторі на принципах креативної щирості» (курсив автора. - О. П.) [23, с. 80].

Звертається Людмила Тарнашинська до категорії креатора й науково прочитуючи філософський дискурс художньо-естетичного явища шістдесятництва в цілому. На їі думку, серед різноманіття індивідуумів філософського феномену шістдесятництва (людина свідома, людина відповідальна, трагедійна, деміургічна, амбітна тощо) для людини творчої - creator - процес творення художньої реальності $\epsilon$ «подоланням тотальної самотності як іманентної властивості граничного людського буття (буття-на-межі)» [23, с. 178], для неї характерна апріорна свобода (пригадаємо Сартрове: «Творчість же - це свобода як така. Їй ніщо не передує, вона починається з того, що дотримується своїх власних принципів i, насамперед, власної мети» [19, с. 23-24]). До контекстуального поля міркувань Людмили Тарнашинської варто додати і в дечому суголосні думки філософа Олега Кривцуна, який переконаний, що для художника існує «позитивний тип самотності» як необхідна умова розкриття нових форм творчої свободи [9, с. 44]. За його переконаннями, унікальна самореалізація особистості творця виявляється в акті виходу за межі себе йдеться про стійкий спосіб існування митця, реалізацію своєї індивідуальності через потребу в самоперевершенні: «Здатність і потреба художника в акті творчості виходити за межі себе - ие є він сам, це і є його справжнє життя в особливому, ним самим витвореному світі. Безмежна вірність художника вимогам творчості і формує його особливу психологічну подобу, визначає особливі риси його долі, життевого шляху» [9, с. 46; курсив автора. - О. П.].

Відтак вкладаючи в категорію креатора такі смислові аспекти, як взаємозв'язок твору і самоактуалізованого, самоперевершеного творця, наділеного вищим ступенем творчої потенції чи то високим показником креативності, подальшим кроком бачиться пошук його мистецьких інтерпретацій, тобто естетично-чуттєвих моделювань. Йдеться про специфіку художнього сприйняття та відображення в образі креатора-письменника скульптурою, живописом, кінематографом, театром на змістовому і смисловому рівнях. Це цілком виконуване завдання, виходячи 3 методологічних пропозицій Дмитра Наливайка щодо вирішення актуальної проблеми літератури в системі мистецтв. «Література, зауважує дослідник-компаративіст, - це словесні художні твори, словесне мистецтво, проте його художня мова не вичерпується вербальним рівнем, його зміст виражається словесними засобами, але не зводиться до словесного вираження, що $є$ широким полем для взаємодій літератури з несловесними мистецтвами. Адже в художньому словесному творі всі компоненти форми від композиції до ритміки й інтонації естетично значущі й виконують функції вира- 
ження художнього змісту, який є феноменом, не ідентичним емпіричному „життєвому змісту”. Згадані взаємодії відбуваються головним чином на рівні метамови літератури й живопису, скульптури, музики, архітектури та інших мистецтв» [12, с. 27].

Власне наукове прочитання художньо-інтерпретаційних моделей креатора - пластичний образ, кінообраз, театральний образ - розширює межі бачення того, у який спосіб психологічно-творча природа митця сприйнята в емоційноестетичному ракурсі, осягнуто ii зміст [7, с. 100-104]. Художній образ як суб' єктивна духовно-душевна реальність, психічне першоджерело, що виникає у внутрішньому світі творця внаслідок контакту із зовнішнім світом, презентує реальність у модусі більшого чи меншого ізоморфізму (подібності формі), реалізовуючись у процесі естетичного сприйняття конкретним реципієнтом [3, c. 232-235]. У випадку з письменницькою постаттю іï художнє осмислення митцем (художником, скульптором, режисером), з одного боку, передбачає модус більшого ізоморфізму - йдеться про близькість до біографічної особистості, фізіологічно виразних рис людини тощо, проте з іншого, можливий і модус меншого ізоморфізму за умови, що конкретний реципієнт здатен схопити психологічно-духовний стрижень творчої особистості автора, а, на думку Миколи Гартмана, образотворче мистецтво, будучи близьким до поезії (літератури в цілому), здатне зачіпати «душевне буття людини» [6, с. 241]. Саме художньо-інтерпретаційні моделі особистості письменника, вибудувані за модусом меншого ізоморфізму, становлять науковий інтерес у досліджуваній парадигмі «психотип - креатор - образ».

Отже, наближення до творчої особистості письменника 3 інтердисциплінарним інструментарієм, що передбачає співпрацю на перетині проблем гуманітарних галузей із залученням відповідного методологічного досвіду [2, с. 279], - психології, літературознавства і мистецтвознавства - дозволяє осмислити його психологічну і творчу сутність як органічну єдність. Завдяки обраному руху дослідження від психотипу до креатора і від креатора до образу письменницька постать як об'єкт наукового прочитання увиразнюється шляхом виявлення ії психологічної конституції, зумовленості психологічною природою художнього стилю автора при здійсненні цілісної інтерпретації його творчого доробку, детального аналізу моделювання образу письменника образотворчим i візуальним мистецтвами у пошуку взаємозалежності між об'єктом зображення та специфікою психологічно-творчої сутності креатора.

\section{ЛІТЕРАТУРА}

1. Беловодский С. А. Франц Грильпарцер : Ранний период творчества; психотип и проблемы творческой самореализации: автореф. дис. ... канд. филол. наук: 10.01.03 / Воронеж. гос. ун-т. Воронеж, 2002. 22 c.

2. Будний В., Ільницький М. Порівняльне літературознавство : підручник. Київ : ВД «КиєвоМогилянська академія», 2008. $430 \mathrm{c}$.

3. Бычков В. В. Эстетика : учебник. Москва : КНОРУС, 2012. 528 с.

4. Егоров О. М. Ю. Лермонтов как психологический тип : монография. Москва : КогитоЦентр, 2015.360 с. 
5. Франко I. Із секретів поетичної творчості. Франко I. Зібрання творів: у 50-ти тт. Т. 31. Київ : Наук. думка, 1981. С. 45-119.

6. Гартман Н. Эстетика / пер. с нем. Киев : Ника-Центр, 2004. 640 с.

7. Іванишин В. П. Нариси 3 теорії літератури : навч. посіб. Київ : ВЦ «Академія», 2010. $256 \mathrm{c}$.

8. Кэмпбелл Д. Пути к блаженству : мифология и трансформация личности / изд. и предисл. Д. Кадлера ; пер. с англ. А. Осипова. Москва : Открытый мир, 2006. 320 с.

9. Кривцун О. А. Психология искусства. Москва : Изд-во Лит. ин-та им. А. М. Горького, 2000. 224 c.

10. Моклиця М. Модернізм як структура : Філософія. Психологія. Поетика. 2-ге вид., доп. і перероб. Луцьк : РВВ «Вежа» Волинського держ. ун-ту ім. Лесі Українки, 2002. 390 с.

11. Морозов А. В., Чернилевский Д. В. Креативная педагогика и психология: учеб. пос. 2-е изд., испр. и доп. Москва : Академический Проект, 2004. 560 с.

12. Сучасна літературна компаративістика : стратегії і методи: антологія / за заг. ред. Д. Наливайка. Київ : Вид. дім «Києво-Могилянська академія», 2009. 488 с.

13. Негус К., Пикеринг М. Креативность. Коммуникация и культурные ценности / пер. с англ. О. В. Свинченко. Харьков : Изд-во Гуманитарный Центр, 2011. 300 с.

14. Немов Р. С. Психологический словарь. Москва : Гуманитар. изд. центр ВЛАДОС, 2007. $560 \mathrm{c}$.

15. Овсянико-Куликовский Д. Н. Литературно-критические работы : в 2 т. Москва : Худ. лит., 1989. Т.1 : Статьи по теории литературы ; Гоголь ; Пушкин ; Тургенев ; Чехов / сост., примеч. И. Михайловой ; вступ. статья Ю. Манна. 542 с.

16. Овсянико-Куликовский Д. Н. Вопросы психологии творчества : Пушкин. Гейне. Гете. Чехов. К психологии мысли и творчества. Изд. 2-е. Москва : Изд-во ЛКИ, 2008. 304 с.

17. Плеханова И. И. Философские проблемы литературоведения : Теория витальности в связи с философией, теорией и практикой литературного творчества. Психотип и творческая индивидуальность поэта. Иркутск : Изд-во ИГУ, 2014. 270 с.

18. Плеханова И. И. Психотип поэта: цель и методика определения (на примере творчества Ксении Некрасовой). Филологический класс. 2014. № 3(37). С. 19-24. URL: http://elar.uspu.ru/bitstream/uspu/558/1/flks-2014-03-03.pdf (дата звернення: 07.07.2018).

19. Сартр Ж. П. Бодлер / пер. с фр. Г. К. Косикова. Изд. 2-е. Москва : Едиториал УРСС, 2004. $184 \mathrm{c}$.

20. Шарп Д. Типы личности. Юнговская типологическая модель / пер. с англ. СанктПетербург : Б.С.К., 1996. 216 c. URL: https://www.litmir.me/br/?b=285032 (дата звернення: 19.11.2018).

21. Скупейко Л. І. Іван Франко про творчу індивідуальність письменника. Київ : Наук. думка, 1986. $136 \mathrm{c.}$

22. Самототожність письменника. До методології сучасного літературознавства : колективна монографія / відп. ред. Г. М. Сивокінь. Київ : Укр. книга, 1999. 160 с.

23. Тарнашинська Л. Презумпція доцільності : Абрис сучасної літературознавчої концептології. Київ : ВД «Києво-Могилянська академія», 2008. 534 с.

24. Якобсон П. М. Психология художественного творчества. Москва : Знание, 1971.48 с. 25. Юнг К. Г. Психологические типы / пер. С. Лорие. Минск : ООО «Харвест», 2003. 528 с.

\section{REFERENCES}

1. Belovodskij, S.A. (2002), Franz Grillpacker: Early Creation Period; psychotype and problems of creative self-realization: Author's thesis [Franc Grilparcer: Rannij period tvorchestva; psihotip i problemy tvorcheskoj samorealizacii: avtoref. dis. ... kand. filol. nauk], Voronezh, 22 p. (in Russian).

2. Budnyi, V., Ilnytskyi, M. (2008), Comparative Literary Studies [Porivnialne literaturoznavstvo], VD "Kyievo-Mohylianska akademiia", Kyiv, 430 p. (in Ukrainian).

3. Bychkov, V.V. (2012), Aesthetics [Ehstetika], KNORUS, Moskva, 528 p. (in Russian). 
4. Egorov, O. (2015), M.Yu. Lermontov as a psychological type [M.Yu. Lermontov kak psihologicheskij tip], Kogito-Centr, Moskva, 360 p. (in Russian).

5. Franko, I. (1981), From the secrets of poetic creativity, Collected works in 50 vols. Vol. 31 [Iz sekretiv poetychnoi tvorchosti, Zibrannia tvoriv u 50 t. T. 31], Nauk. dumka, Kyiv, pp. 45-119. (in Ukrainian).

6. Gartman, N. (2004), Aesthetics, trans. from Ger. [Ehstetika, per. s nem.], Nika-Centr, Kiev, 640 p. (in Russian).

7. Ivanyshyn, V.P. (2010), Essays on the theory of literature [Narysy $z$ teorii literatury], Akademiia, Kyiv, 2010. 256 p. (in Ukrainian).

8. Kehmpbell, D. (2006), Ways to Bliss: Mythology and Personality Transformation, trans. from Eng. [Puti k blazhenstvu: mifologiya i transformaciya lichnosti, per. s angl], Otkrytyj mir, Moskva, 320 p. (in Russian).

9. Krivcun, O.A. (2000), Psychology of art [Psixologiya iskusstva], Izd-vo Lit. in-ta im. A.M. Gorkogo, Moskva, 224 p. (in Russian).

10. Moklytsia, M. (2002), Modernism as a structure: Philosophy. Psychology. Poetics, $2^{\text {nd }}$ ed. [Modernizm yak struktura: Filosofiia. Psykholohiia. Poetyka, vyd. 2], RVV "Vezha" Volynskoho derzh. un-tu im. Lesi Ukrainky, Lutsk, 390 p. (in Ukrainian).

11. Morozov, A.V. and Chernilevskij, D.V. (2004), Creative pedagogy and psychology, $2^{\text {nd }}$ ed. [Kreativnaya pedagogika i psihologiya, izd. 2], Akademicheskij Proekt, Moskva, 560 p. (in Russian).

12. Nalyvaiko, D. (Ed.). (2009), Modern literary comparativism: strategies and methods [Suchasna literaturna komparatyvistyka: stratehii $i$ metody], Vyd. dim "Kyievo-Mohylianska akademiia", Kyiv, 488 p. (in Ukrainian).

13. Negus, K. and Pickering, M. (2011), Creativity. Communication and cultural value, trans. from Eng. [Kreativnost. Kommunikaciya i kulturnye cennosti, per. s angl.], Izd-vo Gumanitarnyj Centr, Harkov, 300 p. (in Russian).

14. Nemov, R.S. (2007), Psychological dictionary [Psihologicheskij slovar], Gumanitar. izd. centr VLADOS, Moskva, 560 p. (in Russian).

15. Ovsyaniko-Kulikovskij, D.N. (1989), Literary and critical works in 2 vols. Vol. 1 [Literaturnokriticheskie raboty v 2 t. T. 1] Hud. lit., Moskva, 542 p. (in Russian).

16. Ovsyaniko-Kulikovskij, D.N. (2008), Questions of the psychology of creativity: Pushkin. Heine. Goethe. Chekhov. To the psychology of thought and creativity, $2^{\text {nd }}$ ed. [Voprosy psihologii tvorchestva: Pushkin. Gejne. Gete. Chekhov. K psihologii mysli i tvorchestva, izd. 2], Izd-vo LKI, Moskva, 304 p. (in Russian).

17. Plekhanova, I.I. (2014), Philosophical problems of literary criticism: Theory of vitality in connection with philosophy, theory and practice of literary creation. Psychotype and creative personality of the poet [Filosofskie problemy literaturovedeniya: Teoriya vitalnosti $v$ svyazi $s$ filosofiej, teoriej i praktikoj literaturnogo tvorchestva. Psihotip i tvorcheskaya individualnost poehta], Izd-vo IGU, Irkutsk, 270 p. (in Russian).

18. Plekhanova, I.I. (2014), "The psychotype of the poet: the purpose and method of definition (on the example of creativity Ksenia Nekrasova)" ["Psihotip poehta: cel' i metodika opredeleniya (na primere tvorchestva Ksenii Nekrasovoj)"], Filologicheskij klass, No. 3, pp. 19-24, available at: http://elar.uspu.ru/bitstream/uspu/558/1/flks-2014-03-03.pdf (in Russian).

19. Sartr, Zh.P. (2004), Baudelaire, trans. from French, $2^{\text {nd }}$ ed. [Bodler, per. s fr., izd. 2], Editorial URSS, Moskva, 184 p. (in Russian).

20. Sharp, D. (1996), Types of personality. Jung Typological Model, trans. from Eng. [Tipy lichnosti. Yungovskaya tipologicheskaya model, per. s angl.], B.S.K, Sankt-Peterburg, 216 p., available at: https://www.litmir.me/br/?b=285032 (in Russian).

21. Skupeiko, L.I. (1986), Ivan Franko about the creative personality of the writer [Ivan Franko pro tvorchu indyvidualnist pysmennyka], Nauk. dumka, Kyiv, 136 p. (in Ukrainian).

22. Syvokin, H.M. (Ed.). (1999), Self-identity of the writer. To the methodology of modern literary studies [Samototozhnist pysmennyka. Do metodolohii suchasnoho literaturoznavstva], Ukr. knyha, 
Kyiv, 160 p. (in Ukrainian).

23. Tarnashynska, L. (2008), Presumption of expediency: the Abris of Contemporary Literary Concepts [Prezumptsiia dotsilnosti: Abrys suchasnoi literaturoznavchoi kontseptolohii], VD "Kyievo-Mohylianska akademiia", Kyiv, 534 p. (in Ukrainian).

24. Yakobson, P.M. (1971), Psychology of artistic creation [Psihologiya hudozhestvennogo tvorchestva], Znanie, Moskva, 48 p. (in Russian).

25. Yung, K.G. (2003), Psychological types [Psihologicheskie tipy], OOO “Harvest”, Minsk, 528 p. (in Russian).

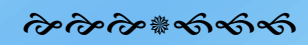

